\title{
Козырева Е.А.
}

\section{Ближние усадьбы высшей знати, как феномен историко-градостроительной жизни Санкт-Петербурга, на примере дворцово-паркового ансамбля Сергиевки}

Санкт-Петербургский государственный архитектурно-строительный университет (Россия, Санкт-Петербург)

doi: $10.18411 / \mathrm{j}-10-2018-119$

idsp: 000001:lj-10-2018-119

\section{Аннотация}

В работе рассматриваются этапы строительства, реконструкции дворцовопаркового ансамбля Сергиевка, как одного из примеров ближних усадеб высшей знати. Проанализированы уникальные объекты, расположенные на территории ансамбля, и их современное состояние. Проблемы сохранения и приспособления для современного использования в настоящее время.

Ключевые слова: усадьбы высшей знати, Дворцово-паркового паркового ансамбля Сергиевка, проблемы сохранения объекта.

В Санкт-Петербурге и вокруг Санкт-Петербурга до 1917г можно отметить наличие усадеб, которые по амбициозности и своему содержанию, могут в чем-то поспорить с Императорскими загородными дворцово-парковыми комплексами. В тоже время имеют характерные отличительные особенности, благодаря которым их можно обозначить как «ближние усадьбы высшей знати». А так же можно отличить как от Императорских дворцовых загородных комплексах, так и от помещичьих усадеб. [5, с. 17].

Эти усадьбы создавали великолепные миры вокруг столичного города и были амбизиозными центрами притяжения, зачастую предрешая судьбу владельцев (Каменный остров - Бестужев-Рюмин). Сергиевки.

Одним из примеров таких усадьб является дворцово-парковый ансамбль

Парк усадьбы «Сергиевка» организован на месте естественного леса. На картах 1710-1720-х годов среди относительно густых россыпей частновладельческих наделов один из больших, никак не и обозначенных именем владельца, является «перегон» между владениями И. С. Потемкина к востоку от будущей Собственной дачи и Л. И. Румянцева на месте будущей Сергиевки. [1; 7, с. 291]

Пейзажная планировка парка сложилась не ранее последней четверти XVIII столетия, так же как и разветвленная гидросистема, привязанная к формам пейзажного парка.

По-видимому, одним из старейших сооружений усадьбы является так называемый Китайский павильон или Китайский домик (Круглый Графский, Строгановский) на восточном берегу Оранжерейного пруда. Каменное здание выделяется скругленными углами и высокой кровлей, далеко вынесенной за периметр стен здания и опирающейся на столбы. Не исключено, что сооружение его было произведено еще в XVIII веке, когда была распространена мода на «китайщину», но в последние строительные эпохи от этого стиля здание сохранило лишь характер кровли, слуховых окон да обходную галерею на деревянных столбах. [4, с. 287]

Источник «Голова» (или «Адамова голова»), являющийся достопримечательностью парка и находящийся на западном склоне Восточного оврага, был создан в 1801 году по проекту архитектора Ф. Броуэраи повелению императора Павла I.

В 1839 году Николай I подписывает указ о покупке дачи, 7 марта оформляется купчая крепость на имя великой княгини Марии Николаевны. Гидротехнические сооружения подновлялись по проектам архитектора Ф. Броуэра. Около 1840 года к 
работам привлекается выдающийся садовый мастер П. И. Эрлер, с именем которого связны многие важные работы в парках Петродворца. [4, с. 297]

Проектирование обновляемой резиденции было поручено архитектору А.И. Штакеншнейдеру. С начала 1839 года архитектор занимается проектом строительства Сергиевской усадьбы. [2, с. 170]

На протяжении 1839-1842 годов было создано ядро обновленного ансамбля Сергиевка. Штакеншнейдер отказался от планировки основного дворцового здания по одной оси или «покоем», как и вообще от тяжеловесных и нерасчлененных масс, от традиционной симметрии этих масс. Не снижая репрезентативного характера своих построек, зодчий значительное внимание уделил функциональной стороне, удобству обитания владельцев усадьбы. [7, с. 295]

Следующий этап строительства на территории Сергиевки ведется в $1843-1850$ годах. В 1843 году в Сергиевке построен чугунный мост на каменных устоях. Мост был разрушен в период 1941-1944 годов. [3, с. 40]

В этот же период по проекту Штакеншнейдера были построены еще два сооружения - церковь Св. Александры (капелла) и Чайный домик. Руины небольшого прямоугольного одноэтажного здания церкви можно найти среди зарослей на южной границе обширного луга перед дворцом, с трехчастными окнами и остатками портала на западном фасаде. Главной отличительной особенностью Капеллы было то, что здесь впервые в России и в мире ансамбль скульптур был выполнен в технике гальванопластики: новой технологии, изобретателем которой являлся известный ученый академик Б. С. Якоби. [4, с. 298]

Многочисленные скульптуры украшали интерьеры усадебных зданий, стояли во многих уголках парка (по преимуществу — копии с «антиков»). В 1920-х годах все эти скульптуры были признаны «не имеющими художественной ценности», и к началу последующего десятилетия расхищены или сданы в утиль. «Капелла» использовалась в качестве склада для хлорной извести, а затем горючесмазочных материалов. В войну здание частично пострадало; в конце 1940-х годов с него сняли беломраморную облицовку для реставрации колоннад в Нижнем парке Петергофа.

Второе сооружение Штакеншнейдера этого периода — Чайный домик, который размещался примерно на западной границе Дворцового луга на полпути между дворцом и Капеллой. В начале 1920-х годов оно представляло собой руины. [7, с. 297]

На сегодняшний день сохранились основные элементы архитектурного ансамбля, каковым он был на момент расцвета. Полностью сохранилось основное ядро, включающее дворец и флигели для прислуги хозяйственных построек. Реставрация сохранила общее художественно-стилистическое решение дворца. Сохранилась планировка парка и часть парковых построек. Водная система реки, прудов и ручьев с мостами и плотинами, по-прежнему, формирует парковую среду.

В Сергиевке можно отметить наличие уникальных объектов: оранжереи, ферма, церковь, различные павильоны, скульптуры, разветвленная гидросистема, плотины, мосты, фонтаны, грот, купальня, кухонный и гофмейстерский корпуса. Именно эти объекты дают нам возможность отнести Сергиевку не к дворянским или помещичьим усадьбам, а выделить в отдельный тип.

К сожалению, утрачены церковь, фонтан, некоторые павильоны. Почти без утрат дошел до сегодняшнего дня комплекс зданий: Гофмейстерский (или Кавалерского) корпус и хозяйственные постройки рядом с дворцом. Церковь Св. Александры (капелла) в руинированном состоянии. Чайный домик полностью утрачен. Китайский павильон или Китайский домик (Круглый Графский, Строгановский) на восточном берегу Оранжерейного пруда в удовлетворительном состоянии. Скульптура «Голова» (или «Адамова голова») утратила шлем и все глубже уходит в землю.

Таких усадеб, как Дворцово-паркового ансамбля Сергиевки, в разное время было не более 50, некоторые из них частично сохранились и дошли до наших дней (усадьба 
Дашковой Е.Р. «Кирьяново» на проспекте Стачек, усадьба Аничкова на набережной реки Фонтанки), некоторые остались в истории и воспоминаниях современников тех лет («Пелла» в поселке Оредеж, усадьба Буксгевдена - ныне Полежаевский парк), некоторые были выкуплены в казну, и мы их знаем, как императорские резиденции (Елагин остров, Таврический дворец). В настоящее время требуется сохранение и приспособление этого исторически сложившегося феномена «ближних усадеб высшей знати» не только как градостроительных объектов, но и как фундаментальных следов развития культуры и дореволюционной жизни города. Столичный Санкт-Петербург не мог оставаться только в границах императорских резиденций, не мог существовать без этого великолепного ожерелья пригородных усадеб высшей знати.

$$
* * *
$$

1. Карта окрестностей С.-Петербурга (до Ораниенбаума). 1710-е гг. (ЦГАБМФ РФ, ф. 3/Л, оп. 25, д. 1974.Топографическая карта С.-Петербурга и его окрестнос`тей).

2. Новиков Ю.В. Собственная дача и Сергиевка в Старом Петер-гофе // Памятники истории и культуры Санкт-Петербурга: Исследования и материалы. Вып. 4. - СПб.: «Белое и Черное», 1997. — С. 132-177.

3. Якоби Б. С. Об ученых трудах Его Императорского Высочества покой Лейхтенбергского // Ученые записки Импера ${ }^{-т о р с к о и ̆ ~ А к а д е м и и ~ н а у к . ~ С П б ., ~ 1845, ~ т . ~ И, ~ в ы п . ~ 1, ~ с . ~ 37-~}$ 41.

4. Пыляев, М. И. Забытое прошлое окрестностей Петербурга / М. И. Пыляев. - Л. : Лениздат, 1996. - 670 c.

5. Семенцов, С. В. Развитие регулярной Санкт-Петербургской агломерации после Петра Великого и проблемы ее сохранения как Объекта Всемирного наследия / С. В. Семенцов. // Вестник гражданских инженеров. - 2014. - 4. - С. 16-24.

6. Федеральный закон от 25.06.2002 № 73-Ф3 «Об объектах культурного наследия (памятниках истории и культуры) народов Российской Федерации» // «Парламентская газета», №120-121, 29.06.2002

7. С.Б. Горбатенко. Петергофская дорога : историко-архитектурный путеводитель / С. Б. Горбатенко. Санкт-Петербург : Европейский дом, 2002. - 448 с.

\section{Козырева Е.А., Блинова А. \\ Ближние усадьбы высшей знати, как феномен историко-градостроительной жизни Санкт-Петербурга, на примере усадьбы Шереметьева на Фонтанке}

Санкт-Петербургский государственный архитектурно-строительный университет doi: $10.18411 / \mathrm{j}-10-2018-120$

(Россия, Санкт-Петербург)

idsp: 000001:lj-10-2018-120

\section{Аннотация}

В работе рассматриваются этапы строительства, реконструкции усадьбы Шереметьева, как одного из примеров ближних усадеб высшей знати. Проанализированы уникальные объекты, расположенные на территории ансамбля, и их современное состояние. Проблемы сохранения и приспособления для современного использования в настоящее время.

Ключевые слова: усадьбы высшей знати, усадьба Шереметьева на Фонтанке, проблемы сохранения объекта.

В Санкт-Петербурге и вокруг него до 1917г можно отметить наличие усадеб, которые по своему содержанию и амбициозности, могут в чем-то поспорить с Императорскими загородными дворцово-парковыми комплексами. Но в тоже время имеют характерные отличительные особенности, по которым их можно отделить как от Императорских дворцовых загородных комплексах, так и от помещичьих усадеб. Такой особый тип объектов можно обозначить как «ближние усадьбы высшей знати». Усадьбы (точнее - дворцово-парковые комплексы) высшей знати традиционно развивались как особый тип объектов на прилегающей к столичному городу 